\title{
Joint Range of Motion Decreased
}

National Cancer Institute

\section{Source}

National Cancer Institute. Joint Range of Motion Decreased. NCI Thesaurus. Code C78403.

Decreased joint flexibility. 